\title{
Representing two road traffic collisions in one Accimap: Highlighting the importance of emergency response and enforcement in a low-income country
}

Omar Faruqe Hamim ${ }^{\mathrm{a}^{*}}$, Md. Shamsul Hoque ${ }^{\mathrm{b}}$, Rich C. McIlroy ${ }^{\mathrm{c}}$, Katherine L. Plant ${ }^{\mathrm{c}}, \&$ Neville A. Stanton ${ }^{\mathrm{c}}$

${ }^{a *}$ Corresponding author. Lecturer, Department of Civil Engineering, Bangladesh University of Engineering and Technology, Dhaka-1000, Bangladesh. Email: hamim1204007@gmail.com

${ }^{\mathrm{b}}$ Professor, Department of Civil Engineering, Bangladesh University of Engineering and Technology, Dhaka1000, Bangladesh

${ }^{\mathrm{c}}$ Human Factors Engineering, Transportation Research Group, University of Southampton, Southampton, UK

\begin{abstract}
Seemingly erratic pedestrian crossing has become a major source of vehiclepedestrian collisions on highways in Bangladesh, and across other low- and middle-income countries (LMICs). In this article, we approach the challenge from a sociotechnical systems perspective by using the Accimap method to analyse a pair of time-separated yet interconnected road traffic collisions. The first event involved a truck colliding with a road divider; in the second, fatal incident, a bus hit a university student. The traditional-style investigation conducted immediately after the collision apportioned blame to end users i.e. drivers and pedestrian; however, application of sociotechnical systems thinking revealed the contribution from lack of emergency response and enforcement among many other important factors. Results and recommendations are discussed in terms of reducing the chance and severity of such collisions across LMICs, and in terms of the need to look beyond the end-user, a focus that remains dominant in such settings.
\end{abstract}

Keywords: Sociotechnical systems; road safety; Accimap; low-income country; vehiclepedestrian collision.

\section{Practitioner Summary}

This paper applies sociotechnical systems thinking to pedestrian safety in Bangladesh by analysing two inter-connected road traffic collisions using a single Accimap. The findings emphasise the importance of implementing road safety interventions that target all system levels, and draw attention to the importance of post-collision response in low-income settings. 


\section{INTRODUCTION}

Road trauma is a major public health issue, particularly across low- and middle-income countries (e.g., WHO, 2018); Bangladesh is no exception. The recent rise in collision statistics has led the government to take various countermeasures to tackle this ever-increasing challenge. Despite measures taken by the government following an unprecedented student movement for road safety (BBC News, 2018), the numbers of road crashes and fatalities have been increasing compared to those of the previous year. According to police data, 2,635 people were killed and 1,920 people were injured in 2,609 road crashes in 2018, whereas in 2017, 2,513 people died and 1898 people got injuries in 2,562 road traffic collisions; however, the number of road traffic collisions, deaths and injuries reported by police is significantly less than those reported by voluntary organizations collected based on media reports (reported in The Daily Star, 2019).

Rather than continuing with traditional methods, it has been argued that systems based approaches to incident investigation would offer greater benefits to road safety in Bangladesh. The systems approach is now a prominent paradigm in incident analysis research (e.g. Salmon et al., 2010). It views accidents as the result of unexpected, uncontrolled relationships between a system's constituent parts. Systems-based incident investigations go beyond identifying the direct 'causes' of the incident, contributing also to system-wide improvements in safety (Hollnagel, 2004; Salmon et al., 2012). The sociotechnical systems standpoint argues for the importance of the combination of activities of various concerned officials at the decision- and policy-making level of society play (Le Coze, 2015; Trotter et al., 2013, 2014).

Since the 1990s, various systemic incident analysis techniques have been developed for responding to the increased level of complexity of socio-technical systems, covering a wide range of domains, e.g., healthcare, nuclear power, rail, mining and marine transportation (Waterson et al., 2015, 2017; Larue et al., 2020; Donovan et al., 2017). These systemic incident analysis methods are generated on the basis of sociotechnical systems and control theory (e.g., Accimaps - Rasmussen (1997), STAMP - Leveson (2004)) or resilience engineering (e.g., FRAM - Hollnagel (2004)). Among these methods, Accimap has been singled out as being particularly applicable to the road transport domain (Stanton et al., 2019). In this paper, Rasmussen's Accimap approach has been used to analyse two road traffic collisions in a lowincome setting, where one incident acted as the trigger for the other. An attempt has been taken 
to extend the application of Accimap in investigating two time-separated road traffic collisions rather than analysing each single incident independently. The purpose of the analysis was to generate road safety intervention recommendations that are relevant from a sociotechnical systems perspective, and to demonstrate the flexibility of the Accimap approach in representing two, inter-related collisions.

Across domains, the majority of systems based research has been performed in high-income countries (e.g., Cassano-Piche, Vicente, and Jamieson, 2009; Nayak and Waterson, 2016; Waterson, 2020; Tabibzadeh and Meshkati, 2015; Nyman and Johansson, 2015; Murphy et al., 2018). Nevertheless, there are recent examples of the approach being applied in low-income settings. Preliminary efforts can be seen in the works of McIlroy et al. (2019), Hamim et al. (2019, 2020), and Hamim and Hoque (2019). We build on this research, and further develop the use of Accimaps for road traffic collision analysis in low-income settings in this paper, through the analysis of a fatal vehicle-pedestrian collision that itself was triggered by a collision between involving a heavy-duty vehicle and nose of a road divider. Accimaps highlight the interactions, communication and interoperability within and between levels of the system, representing a group of actions, events, and decision points in the context of a single incident (Lee et al., 2017). The current research represents the first example (to our knowledge) of two, interconnected road traffic collisions being graphically represented through a single Accimap diagram.

The three 'E's of road safety, namely engineering, education, and enforcement, have dominated road safety discussions. McIlroy et al. (2019) expanded this by discussing additional 'E's, including economics, emergency response and enablement. The call for new approaches to road safety came from the fact that global trends have stagnated; fatality rates are not declining, especially in high-income countries. Even though the scenario is not the same in low-income countries like Bangladesh, the application of socio-technical methods for road incident investigations has the potential to provide new insights (see our own previous work; Hamim et al., 2020). A primary motive of systems-based approach to road safety is to propose reformation at system level rather than focusing on discrete factors at the end user level. Taking multiple perspectives of road safety will promote a collaborative, synergistic approach for the reduction in the occurrence and severity of road collisions, one that looks at the system across all hierarchical levels. 
With very limited literature available on the application of sociotechnical systems thinking to road traffic collisions in low-income countries, this article aims to identify key factors at different levels of the road safety system that significantly contributed to the causation of two interconnected road traffic collisions. Additionally, an attempt has been made to find out the interrelations among the chain of events that eventually led to these incidents, and to graphically illustrate these interactions. Further, reformatory activities have been recommended from the six 'E's perspectives referenced above (i.e., education, engineering, enforcement, economics, emergency response, enablement) in order to highlight the importance of thinking about road safety in multiple different ways, and the synergy generated from accumulated application of such proposed remedial measures. Recently, safety system researchers have focussed on methodological developments of Accimap, such as the introduction of a contributing factor classification scheme (Goode et al., 2017), or the use of hybrid models or collision analyses (Waterson et al., 2017). A secondary aim of our work was to contribute to this field of Accimap development literature by demonstrating its utility in a scenario with two related yet time-separated collisions, with one contributing to the other.

\section{METHOD}

\subsection{Rasmussen's Risk Management Framework and Accimap methodology}

Systems are described by Rasmussen's Risk Management Framework (RMF; Rasmussen, 1997) in terms of six levels of abstraction. This framework has received notable recent attention in the road safety domain (e.g. Salmon et al., 2012; Newnam \& Goode, 2015; Scott-Parker et al., 2015; Young \& Salmon, 2015; Parnell et al., 2017). In the current research, an expanded version of the original Risk Management Framework has been employed. This consists of eight levels; international committees, national committees, central government, regulators and associations, industry and local government, resource providers, end users and, equipment and environment (Figure 1; Parnell et al., 2017). Based on the Risk Management Framework, the Accimap (Svedung and Rasmussen, 2000) is a way to graphically illustrate the interrelated actions and decision points (of particular actors) that eventually lead to an incident. This can help the investigators as well as policy-makers to move away from blaming end users, and move towards and understanding of the incident from a systems point of view. 
International committees crossing country boundaries determine performance requirements and targets that member states must follow while setting their own laws.

National committees independent of the government, oversee and review policies, standards and directives.

Government runs the country and the associated departments that define the laws within the country.

Regulations are put in place for successful implementation and enforcement of laws.

Industries and local government supervise and enforce design standards in a localized context.

Implement the functions and services of top level actors for running the manufacturing process by managing resources

External physical and environmental factors that impact on road use.

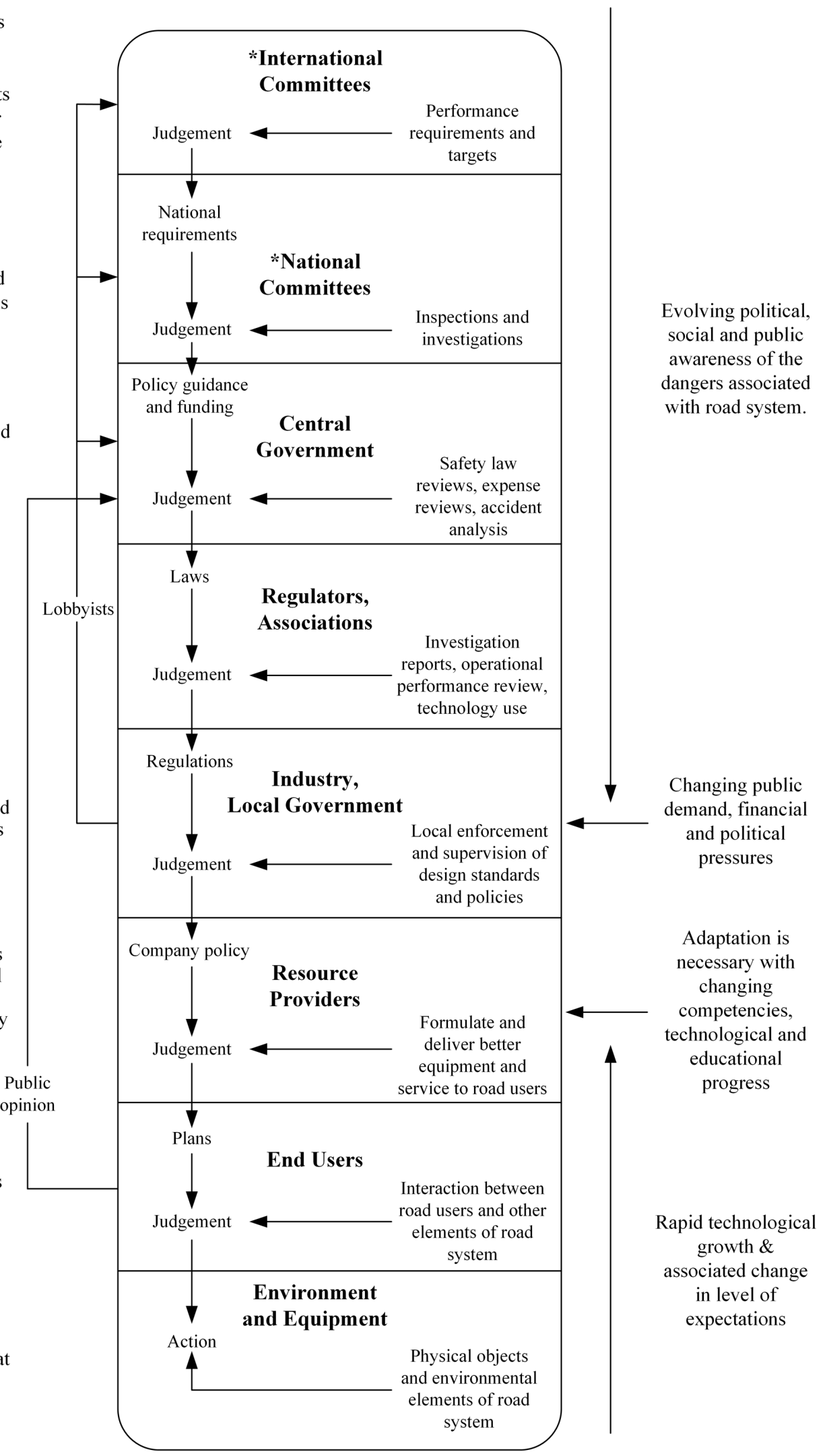

Figure 1. The extended version of Rasmussen's Risk Management Framework. (*levels additional to those described by Rasmussen (1997); adapted from Parnell et al., 2017) 


\subsection{Developing the Accimap}

The Actor Map is a prerequisite of creating an Accimap. We use as a starting point the Actor Map presented in McIlroy et al. (2019), individually for both the primary and secondary incident. The actors relevant to the incidents analysed here were first identified, then the activities undertaken by the identified actors were superimposed. Then, possible interlinks between actors within and across different levels of the system were graphically identified using arrows. The direction of arrow indicates who dictated the initial action and influenced the occurrence of secondary action. The two-way arrows indicate the failure of control by higher-level actors on lower-level actors due to absence of flow of information passed from bottom of the system.

Road traffic collision investigation greatly depends on the availability of information related to the incident under analysis. Newspaper articles and police reports were the primary source of information for developing the Accimaps presented below. Additionally, witness interviews and a first-hand investigation of the scene were performed by the second author in order to validate the information gathered from publicly available sources. Validation of collected information is particularly important in low-income countries, where the collision reporting system is not well-developed and regulated (Heydari et al., 2019). To get comprehensive information about the consecutive incidents selected for this research, multiple visits to the incident site were made, and open-ended questions were posed to the local people who witnessed the incident and have knowledge regarding past incidents that had occurred at the same location. Firstly, the first author generated a draft Accimap based on the validated information and then discussed with other authors. Any discrepancies were mutually solved by deleting actors, adding potential actors or modifying the actions of the actors that actually contributed to the occurrence of the incidents. This research was a part of a multi-country research project, with the UK-based authors of this paper being from a human factors engineering background. Although these authors did not participate in the interviews with witnesses and other immediately-involved parties, they were involved in the iterative development of the Accimap. As such, incident investigation and Accimap development proceeded as follows; the incidents themselves were primarily investigated by the second author shortly after their occurrence; the first author mapped the contributing factors onto the Accimap structure using investigation reports and discussion with the second author; iterative review of the Accimap involved all authors. The final Accimap (presented below) was based 
on the information collected at those interviews, and on several validation iterations made with local stakeholders, including road traffic collision investigators, police personnel, and human factors specialists.

Based on the Accimap, several remedial measures were proposed; these were considered with reference to the six E's described above (i.e., engineering, education, enforcement, economics, emergency response, and enablement). The recommendations were assigned a single ' $E$ ' or multiple 'E's depending on their implications and focus. The Accimap, the proposed recommendations, and their ' $E$ ' assignations were validated via a small panel of subject-matter experts on road design, operation and maintenance. This comprised a professor from the Department of Civil Engineering at BUET, the director of the Bangladesh Road Research Laboratory (BRRL), and a Lecturer at the BUET Accident Research Institute. The feedback from the expert panel helped in modifying the Accimap and list of recommendations as well as the ' $\mathrm{E}$ ' assignations; this occurred iteratively.

Further validation of the mapping of recommendations with respect to the six 'E's was ensured by performing inter-rater reliability analysis among three individual subject-matter experts. Apart from the lead author, two individuals were recruited to carry out this analysis, neither of which was initially involved in the research. Each of the two recruited individuals had been involved in various road safety research activities for more than 10 years. All three individuals separately categorized all of the recommendations. Each recommendation had to be assigned at least one ' $\mathrm{E}$ ' categorization and could have been assigned against multiple 'E's as well if relevant. In order to perform the validation, SPSS version 25 software package was used to calculate intra-class correlation coefficient (ICC) estimates and their $95 \%$ confident intervals, based on a mean-rating $(\mathrm{k}=3)$, absolute-agreement, 2-way mixed-effects model.

\section{RESULTS}

\subsection{Jahangirnagar University incident description}

The case study analysed in this article was chosen as it is indicative of how the lack of enforcement and emergency response to recover from one incident can lead to another incident. It was also chosen due to its prominence; the whole nation, and in particular the university student community, was stirred when a newly admitted university student was killed at the entrance of her own university by a speeding bus. 
On the night of Sunday the $5^{\text {th }}$ into Monday the $6^{\text {th }}$ of September, 2004, a sugar-laden truck hit the nose of a road-divider near the main entrance of Jahangirnagar University, incurring serious vehicular damage. This significantly affected normal traffic movements, causing a temporary blockage of the road. The driver was seriously injured. The accident occurred at about 1:30 am. Post-collision reports summarised the incident as follows; the untreated (i.e., not painted or covered) nose of the road divider caught the truck driver by surprise as he was overtaking another slow vehicle, thus resulting in the truck's collision with the road divider.

Due to this collision, one lane remained closed for the vehicles coming from the center of Dhaka the following day. As a remedial measure, traffic police were present, controlling the contraflow condition, an arrangement by which traffic going in both directions was using only one side of the road. Seeing a line of buses stuck ahead on the road, the bus driver wrongly occupied the opposite lane. Witnesses stated the bus was travelling at high speed. At approximately 8:30 am, a female student named Sumi was crossing the road to get to the bus stop. The bus driver's view of Sumi was obstructed by another large bus standing in the road, and Sumi's vision of the approaching bus was similarly restricted. Sum did not survive the resulting collision.

The incident sparked a massive protest by fellow students. Sumi died within 10 minutes of being run over, but no-one came forward to take her to hospital. This saddened the students so much that they vandalized about 10 roadside shops, setting fire to three of them. They set three buses, four trucks, three CNG-run three-wheelers and five pick-up vans ablaze. Students barricaded the highway, halting traffic movement for about 12 hours, from 9:00 am to 8:30 pm. Thousands of passengers in buses bound for, and leaving the city center, remained stranded on both sides of the blockade.

\subsubsection{Accimap: Jahangirnagar University Incident}

In the Accimap presented in Figure 2, the two consecutive incidents described above have been graphically represented. The dotted boxes in the Accimap below represent the actions leading to the primary incident, and the solid boxes represent actions associated with the secondary incident. Regarding the first incident, where a truck hit the nose of a road divider, present at the Equipment and Environment level were items such as the untreated nose of road divider, insufficient street lighting, and a sudden change of road cross-sectional profile (i.e., varying 
road width). The truck driver's action of overtaking a slow-moving vehicle, and then failing to identify the presence of road divider, is represented at the End User level. A lack of adequate highway design with sufficient safety features, and the absence of driving schools in Bangladesh have been recognized as the factors contributing to the accident at the Resource Providers level, as well as at the Industry and Local Government level. Inadequate police resources for the provision of suitable post-accident recovery, and the absence of a focus on highway safety design from the Roads and Highways department, are presented at the Regulators and Associations level. At the upper levels of the system, a lack of vision from the Bangladesh Planning Commission (National Committees level), and inadequate infrastructural development by the Ministry of Disaster Management and Relief (Central Government level) had contributing effects in the occurrence of the incident. At the International Committees level, the funding of road development projects on a piece-meal basis by Multilateral International Development Banks was a significant contributory factor to this road traffic collision.

As a consequence of the collision between the truck and the road divider, one lane of the twolane highway was blocked, which forced a contra-flow traffic condition at the incident spot. At the Equipment and Environment level, the absence of appropriate traffic control measures, a series of halted large buses, and a lack of pedestrian crossing facilities at the intersection contributed significantly to the actions represented at the End Users level, such as the hurriedness of the bus driver and the seemingly careless road crossing by the pedestrian. Also, the post-accident reaction of the agitated university students (who set fire to roadside shops, vandalized vehicles, and barricaded the highway) caused significant losses to the overall system, including to other road users. At the Resource Providers level, inadequate traffic police staffing levels for controlling the contra-flow, economic pressure on daily wage-based drivers from commercial vehicle operators, and insufficient traffic control measures taken by traffic engineers were the most prominent contributing factors represented in the Accimap. The lack of public transport facilities as provided by Bangladesh Road Transport Corporation, and carelessness on the part of the university authority in ensuring safe pedestrian crossings at university entrances at the Regulators and Associations level, were also identified as contributing factors. At the upper levels of the system, a lack of highway safety design patronized by Ministry of Road Transport and Bridges was noted (at the Central Government level), and a lack of monitoring activities by the National Road Safety Council (at the National 
Committees level), were manifestations of the administrative shortfall that contributed to the occurrence of the incident. Also, inadequate monitoring by the United Nations at International Committees level to achieve the Sustainable Development Goal (SDG) of reducing road traffic accident by $50 \%$ needs also to be addressed.

From the Accimap diagram presented in Figure 2, a number of events corresponding to the primary incident were found to be directly linked with the occurrence of the secondary fatal collision. At the Environment and Equipment level, due to lack of nearby emergency vehicles, the truck damaged in the primary incident could not be removed from the highway; this lane blockage necessitated the contra-flow condition. This acted as a significant factor in the secondary incident. In the case of first collision, an inadequate number of police officers at the Regulators and Associations level lead to a lack of traffic police officers trained to control postincident situations; this played a vital role in the occurrence of the second collision. Additionally, the Roads and Highways Department, as a regulatory authority, was identified as inadequate in terms of the design and construction of the road environment, particularly with regards to following accepted design standards. Not only was this shortfall recognized a significant factor in the causation of primary incident, but was also reflected in the secondary incident. At the Central Government level it was identified that the Ministry of Road, Transport and Bridges lacked sufficient concern for developing highways in line with accepted design standards, incorporating known with safety elements while at the National Committees level, it was supplemented by the fact that National Road Safety Council had insufficient monitoring activities of road safety initiatives taken by different relevant organizations.

The analysis presented in the Accimap supported the proposal of a number of recommendations; these are presented in Table 1, organized according to the Accimap level to which they correspond. The road safety ' $E$ ' perspective to which each recommendation relates is also indicated. For this case study, the inter-rater reliability analysis was performed on 35 samples using the same three independent raters. From this statistical analysis, the Intra Class Coefficient value obtained was 0.989, (CI: 0.982-0.994), indicating an excellent level of reliability (Portney and Watkins, 2000). 


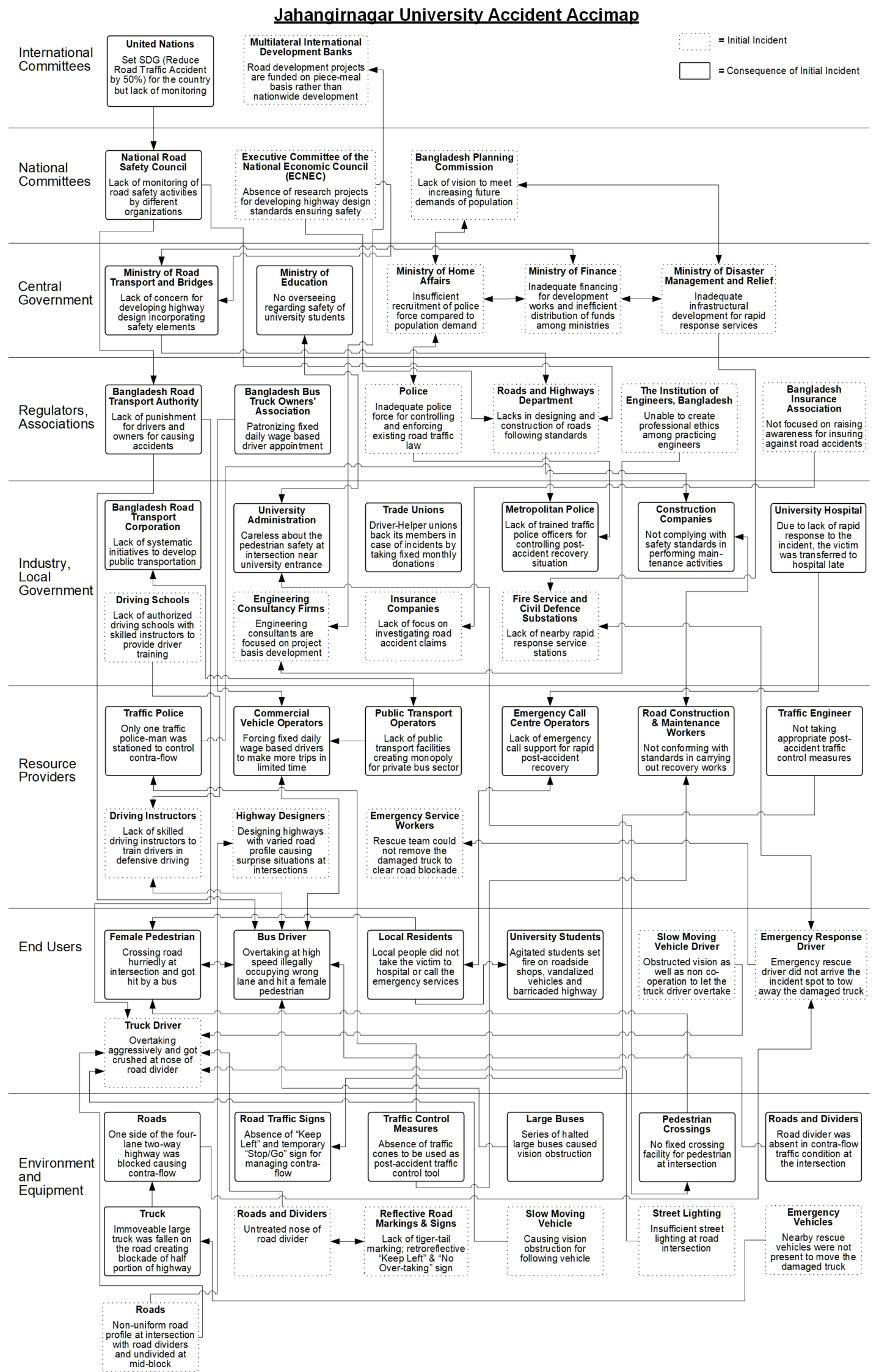

Figure 2: Accimap representing the various interrelated factors contributing to Jahangirnagar University incident 
Table 1. Recommendations corresponding to specific level of the system based on incident events

\begin{tabular}{|c|c|c|c|}
\hline Level & Incident Event & Recommendation & E Approach \\
\hline \multirow[t]{2}{*}{$\begin{array}{l}\text { International } \\
\text { Committees }\end{array}$} & $\begin{array}{l}\text { United Nations set SDG (Reduce Road Traffic Accident } \\
\text { by } 50 \% \text { ) for the country, but lack of monitoring }\end{array}$ & $\begin{array}{l}\text { Legislate that proper monitoring system must be } \\
\text { present for all targets set by international } \\
\text { organizations }\end{array}$ & Enforcement \\
\hline & $\begin{array}{l}\text { Multilateral International Development Banks fund road } \\
\text { development projects on piece-meal basis rather than } \\
\text { nationwide development }\end{array}$ & $\begin{array}{l}\text { Legislate that funds given by international banks } \\
\text { must be spent with a view of nationwide } \\
\text { development }\end{array}$ & $\begin{array}{l}\text { Economics and } \\
\text { Enforcement }\end{array}$ \\
\hline \multirow[t]{3}{*}{$\begin{array}{l}\text { National } \\
\text { Committees }\end{array}$} & $\begin{array}{l}\text { National Road Safety Council inadequately monitors road } \\
\text { safety activities by different organizations }\end{array}$ & $\begin{array}{l}\text { Develop a framework for monitoring the road safety } \\
\text { programs undertaken by different agencies monitored } \\
\text { by National Road Safety Council }\end{array}$ & Enforcement \\
\hline & $\begin{array}{l}\text { Executive Committee of the National Economic Council } \\
\text { (ECNEC) insufficiently funds research projects for } \\
\text { developing highway design standards }\end{array}$ & $\begin{array}{l}\text { Develop a framework to ensure adequate funding } \\
\text { awarded to departments involved in road transport } \\
\text { activities for research projects on highway safety }\end{array}$ & $\begin{array}{l}\text { Economics, } \\
\text { Enforcement } \\
\text { and Enablement }\end{array}$ \\
\hline & $\begin{array}{l}\text { Bangladesh Planning Commission lacks in setting long- } \\
\text { term and sustainable goals to meet increasing future } \\
\text { demands }\end{array}$ & $\begin{array}{l}\text { Focus should shift to long-term, sustainable planning } \\
\text { for resilient infrastructure development to facilitate } \\
\text { emergency response service and ensure enforcement }\end{array}$ & Economics \\
\hline \multirow[t]{5}{*}{$\begin{array}{l}\text { Central } \\
\text { Government }\end{array}$} & $\begin{array}{l}\text { Ministry of Road Transport and Bridges lacks concern for } \\
\text { developing highway design incorporating safety elements }\end{array}$ & $\begin{array}{l}\text { Emphasis must be put on research and development } \\
\text { for better highway design through establishing } \\
\text { research wings in every related department }\end{array}$ & Enablement \\
\hline & $\begin{array}{l}\text { Ministry of Education has no oversight regarding safety } \\
\text { of university students }\end{array}$ & $\begin{array}{l}\text { Develop a wing within the ministry to ensure the safe } \\
\text { passage of students within campus by implementing } \\
\text { safety features and enforcing laws }\end{array}$ & Enforcement \\
\hline & $\begin{array}{l}\text { Ministry of Home Affairs recruits insufficient number of } \\
\text { police officers compared to population demand }\end{array}$ & $\begin{array}{l}\text { Adequate number of police officers need to be } \\
\text { recruited regularly for proper enforcement of laws }\end{array}$ & $\begin{array}{l}\text { Economics and } \\
\text { Enforcement }\end{array}$ \\
\hline & $\begin{array}{l}\text { Ministry of Finance has inadequate financing for } \\
\text { development works and inefficient distribution of funds } \\
\text { among ministries }\end{array}$ & $\begin{array}{l}\text { Funds need to be allocated for development works } \\
\text { and must be distributed equitably among various } \\
\text { ministries as per requirements }\end{array}$ & Economics \\
\hline & $\begin{array}{l}\text { Ministry of Disaster Management and Relief has } \\
\text { inadequate infrastructural development for rapid response } \\
\text { services }\end{array}$ & $\begin{array}{l}\text { Ministry of Disaster Management and Relief must } \\
\text { focus on building post-incident recovery } \\
\text { infrastructures at strategic locations }\end{array}$ & $\begin{array}{l}\text { Emergency } \\
\text { Response }\end{array}$ \\
\hline \multirow{6}{*}{$\begin{array}{l}\text { Regulators } \\
\text { and } \\
\text { Associations }\end{array}$} & $\begin{array}{l}\text { Bangladesh Road Transport Authority do not punish } \\
\text { drivers and owners for causing accidents }\end{array}$ & $\begin{array}{l}\text { Strict punishment must be given by BRTA to drivers } \\
\text { and owners of vehicles causing accidents }\end{array}$ & Enforcement \\
\hline & $\begin{array}{l}\text { Bangladesh Bus Truck Owners' Association patronize } \\
\text { fixed daily wage based driver appointment }\end{array}$ & $\begin{array}{l}\text { Daily wage based driver appointment must be } \\
\text { discouraged instead fixed monthly wage need to be } \\
\text { paid to commercial vehicle drivers }\end{array}$ & Economics \\
\hline & $\begin{array}{l}\text { Inadequate police force for controlling and enforcing } \\
\text { existing road traffic law }\end{array}$ & $\begin{array}{l}\text { Appoint sufficient police force in order to enforce } \\
\text { existing traffic laws }\end{array}$ & $\begin{array}{l}\text { Economics and } \\
\text { Enforcement }\end{array}$ \\
\hline & $\begin{array}{l}\text { Roads and Highways Department (RHD) lacks / does not } \\
\text { follow rigorous road construction and design standards }\end{array}$ & $\begin{array}{l}\text { RHD must follow road safety standards while } \\
\text { designing and constructing roads }\end{array}$ & Engineering \\
\hline & $\begin{array}{l}\text { The Institution of Engineers, Bangladesh (IEB) are unable } \\
\text { to create professional ethics among practicing engineers }\end{array}$ & $\begin{array}{l}\text { IEB must undertake social campaigns throughout the } \\
\text { country to build up professional ethics among } \\
\text { practising engineers }\end{array}$ & Education \\
\hline & $\begin{array}{l}\text { Bangladesh Insurance Association is not focused on } \\
\text { raising awareness for insuring against road accidents }\end{array}$ & $\begin{array}{l}\text { Bangladesh Insurance Association need to focus on } \\
\text { raising awareness for insuring against road accidents }\end{array}$ & $\begin{array}{l}\text { Economics and } \\
\text { Education }\end{array}$ \\
\hline \multirow[t]{10}{*}{$\begin{array}{l}\text { Industry and } \\
\text { Local } \\
\text { Government }\end{array}$} & $\begin{array}{l}\text { Bangladesh Road Transport Corporation (BRTC) lacks } \\
\text { systematic initiatives to develop public transportation }\end{array}$ & $\begin{array}{l}\text { BRTC must introduce sufficient public transportation } \\
\text { to break the monopoly business of private transport } \\
\text { services }\end{array}$ & $\begin{array}{l}\text { Economics and } \\
\text { Engineering }\end{array}$ \\
\hline & $\begin{array}{l}\text { University Administration was careless with regards to } \\
\text { pedestrian safety at intersections near university entrances }\end{array}$ & $\begin{array}{l}\text { University authority must be vigilant in providing } \\
\text { appropriate pedestrian facilities within / around } \\
\text { campus }\end{array}$ & $\begin{array}{l}\text { Engineering } \\
\text { and } \\
\text { Enforcement }\end{array}$ \\
\hline & $\begin{array}{l}\text { Driver-Helper unions back its members in case of } \\
\text { incidents by taking fixed monthly donations }\end{array}$ & $\begin{array}{l}\text { Social awareness needs to be raised to discourage } \\
\text { trade unions favouring dangerous drivers }\end{array}$ & Education \\
\hline & $\begin{array}{l}\text { Metropolitan Police has limited number of trained traffic } \\
\text { police officers for controlling post-accident recovery } \\
\text { situations }\end{array}$ & $\begin{array}{l}\text { Police officers need to be appointed and trained for } \\
\text { posting at important intersections and deployment in } \\
\text { recovery scenarios }\end{array}$ & Enforcement \\
\hline & $\begin{array}{l}\text { Construction Companies do not comply with safety } \\
\text { standards in performing maintenance activities }\end{array}$ & $\begin{array}{l}\text { Legislate and enforce that construction companies } \\
\text { must comply with safety standards in performing } \\
\text { maintenance activities }\end{array}$ & Enforcement \\
\hline & $\begin{array}{l}\text { Due to lack of rapid response to the incident, the victim } \\
\text { was transferred to university hospital late }\end{array}$ & $\begin{array}{l}\text { Rapid response services must be present across } \\
\text { strategic locations in the city to maximise coverage }\end{array}$ & $\begin{array}{l}\text { Emergency } \\
\text { Response }\end{array}$ \\
\hline & $\begin{array}{l}\text { Lack of authorized driving schools with skilled instructors } \\
\text { to provide driver training }\end{array}$ & $\begin{array}{l}\text { Sufficient number of driving schools with skilled } \\
\text { instructors must be established for driver training }\end{array}$ & $\begin{array}{l}\text { Economics and } \\
\text { Education }\end{array}$ \\
\hline & $\begin{array}{l}\text { Engineering Consultancy Firms are focused on project } \\
\text { basis development }\end{array}$ & $\begin{array}{l}\text { Development work must take a wide view rather than } \\
\text { concentrate on isolated project objectives }\end{array}$ & Enforcement \\
\hline & $\begin{array}{l}\text { Insurance Companies do not spend sufficient resources } \\
\text { investigating road accident claims }\end{array}$ & $\begin{array}{l}\text { Insurance Companies must focus on investigating } \\
\text { road accidents claims and promote motor-vehicle } \\
\text { insurance schemes }\end{array}$ & Economics \\
\hline & $\begin{array}{l}\text { Lack of nearby Fire Service and Civil Defence } \\
\text { Substations for rapid response }\end{array}$ & $\begin{array}{l}\text { Fire Service and Civil Defence stations must be } \\
\text { present at strategic locations across the city }\end{array}$ & $\begin{array}{l}\text { Emergency } \\
\text { Response }\end{array}$ \\
\hline
\end{tabular}


Table 1. Recommendations corresponding to specific level of the system based on incident events

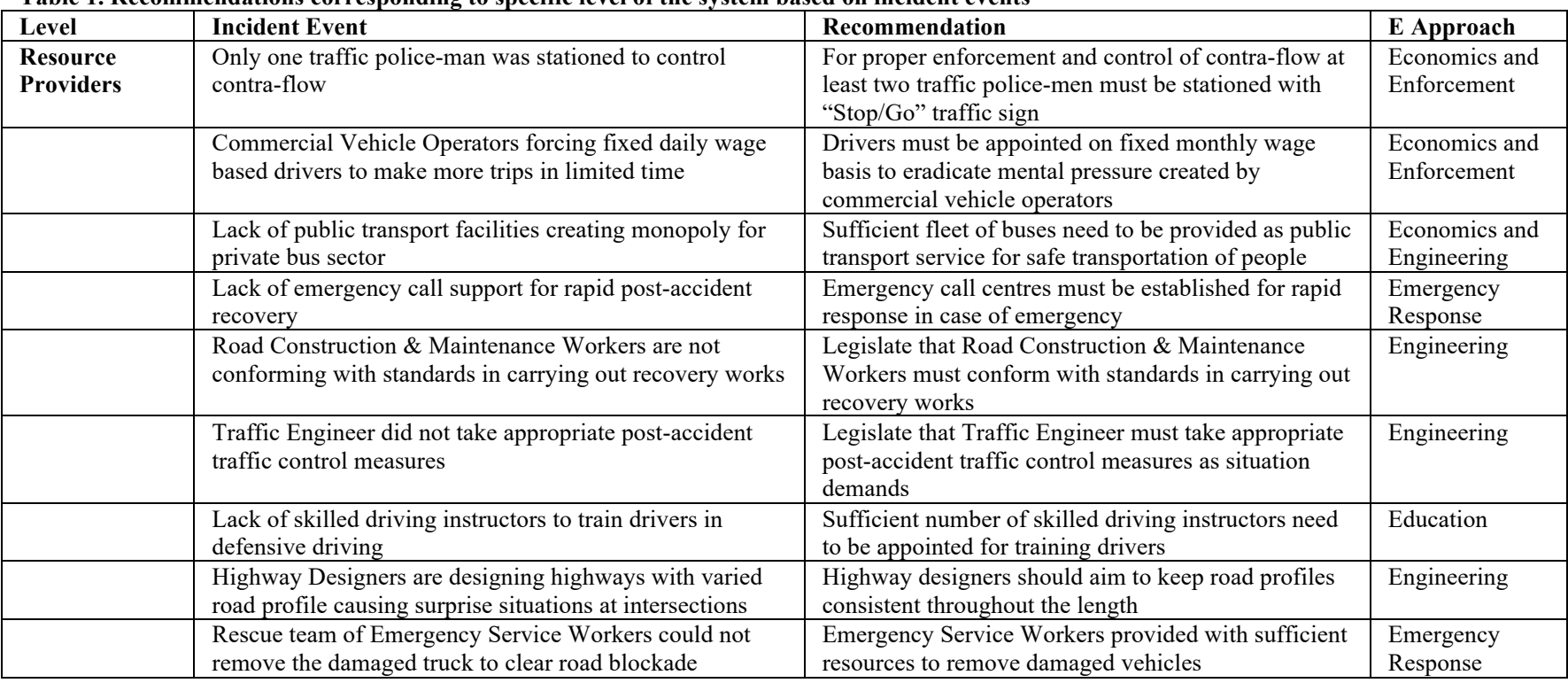

\section{DISCUSSION}

In this study, the first attempt (to our knowledge) has been made to analyse two consecutive road traffic collisions using a single Accimap diagram; i.e., the collision of a truck with the nose of a road divider, and a vehicle-pedestrian collision leading to the death of a university student. The Accimap has previously been employed to analyse single collisions (e.g., Hollnagel and Speziali, 2008; Underwood and Waterson, 2014; Waterson et al., 2017); however, the use of the method to analyse two time-separated, yet interconnected road traffic collisions, is an approach that has not yet received significant attention. This is particularly important in road transport, where road traffic collisions can have a major impact on the functioning of the wider system, and in Bangladesh (and other low-income countries), where the lack of emergency recovery systems can give rise to secondary incidents that can have more serious consequences than the initial system failure.

The advantage of representing two consecutive incidents in a single Accimap diagram was in its graphical representation of the interrelationships among the actions, decisions, and events that led to the two different incidents. The analysis highlighted that if proper rapid rescue operations had been undertaken at the Resource Providers level, to remove the damaged truck from the road, the contra-flow traffic condition (i.e., where both directions of travel were using the same lane, taking it in turns to progress forwards) would not have prevailed the following day. This traffic situation contributed significantly to the secondary, fatal incident. After the primary incident of the truck colliding with the road divider, insufficient traffic police were 
deployed to control the contra-flow road situation. The lack of an adequately staffed police force also contributed to the bus driver being able to violate road law and occupy the wrong lane of the road, and action instrumental in the collision with the pedestrian. At the National Committees level, a failure to include emergency response considerations in the planning stage of infrastructure projects had a significant impact on the connection between the two incidents. Deficiency in designing and constructing highways with consistent road width (by the Roads and Highways Department) resulted in a road design that was inappropriate, insofar as the dividing structure ended abruptly without warning to road users. This unexpected situation affected the truck driver's ability to react in good time, resulting in the collision that ultimately caused half of the road to be blocked. This blockade worked as a passive factor in halting a series of large buses, a procession that subsequently created a vision obstruction for both the bus driver and the pedestrian involved in the secondary incident took.

The benefit of analysing two time-separated yet interconnected road traffic collisions through a single Accimap diagram is in the relative simplicity with which the network of decisions and events leading to the two incidents is graphically represented. This is important for road highlevel safety stakeholders, decision makers, and policy makers (who often have little time to devote each of the issues with which they are faced), insofar as it provides a basis from which to quickly draw their attention to the importance of links between system factors, not only the individual components. This is necessary if we are to make reformations at wider system levels (e.g., through recognizing the interrelated factors between several incidents), yet is something that is not currently seen in policy discussions, particularly in low- and middle-income countries. In future work it would be worthwhile to assess such individuals' perceptions the types of Accimap representations presented here; this could be compared with the more commonly-seen report approach (i.e., a description of events, written in prose, supported with photographs) in terms of information conveyed, understanding of contributory factors, and emotional response (which, although not an evidence-based approach to road safety, does affect media and political attention).

Incorporating two incidents in one Accimap is different to developing two separate Accimaps as it allows (and facilitates) the analyst to highlight direct relationships between the actors, events, and decisions between the two separate collisions. Although in aviation disasters (Branford, 2011), or nuclear power (Waterson et al., 2015, 2017), time-separated events are 
often linked in one Accimap, such application is rare in the road traffic domain. This is likely in part due to the short time scales over which road traffic collisions occur, and the longer time scales over which the events in nuclear of aviation disasters unfold. That said, the wider road transport system can be significantly affected by a single collision, where road closures and clean-up operations are necessary (as in the case described above); system perturbances extend far beyond the collision. This is practically for developing countries like Bangladesh, as it is a common scenario that a lack of proper recovery after one incident leads to the initiation of another incident.

Sixty percent of all road traffic collisions in Bangladesh involve pedestrians (Ahmed and Ahmed, 2013), and the road traffic fatalities seen result from vehicle-pedestrian collisions (ARI, 2015). This is, of course, partly due to very large pedestrian mode share in Bangladesh; however, this does not detract from the fact that more research focussing on this user group is necessary if we are to bring down fatality numbers. According to Metaxatos and Sriraj (2012), although in high-income countries the number of crashes involving vehicles significantly decreased between 2003 and 2007, significant were not seen in the number of crashes with pedestrians (Metaxatos and Sriraj, 2012). Although, Stanton et al. (2019) discussed a collision between a pedestrian wheeling a bicycle and an autonomous Uber vehicle, there is lack of literature focusing on application of socio-technical approaches to analyze vehicle-pedestrian collisions. Several pedestrian collisions have been investigated using a systems approach at level crossings in high-income settings (Stefanova et al., 2015; Metaxatos and Sriraj, 2012) but attempts are yet to be made to investigate vehicle-pedestrian collisions in low-income settings.

The recommendations based on the Accimap are indicative of potential countermeasures to prevent the recurrence of such incident; they are by no means exhaustive. With regards to the ' $E$ ' assignations, that is the road safety lens through they might be considered (see McIlroy et al. 2019), it can be seen that most come under Engineering, Enforcement and Economics. Whereas significant number of recommendations from Education, Emergency Response and Enablement lenses were spotted as well. From this analysis, it can be inferred that the Bangladesh road safety system has deficiencies in all areas at all levels of the sociotechnical system (Hamim et al., 2020). Although deficiencies appear greater in some areas than others, and perhaps merit particular efforts, we must make the point that no one perspective should necessarily be prioritized over another simply because one intervention may be cheap or easy 
to implement. All views should be considered together. Such as concentrating on reformations borrowing investments from multilateral international banks for improving roads from engineering perspective will not improve the road safety if emergency response service is not improved; employing police force for enforcing traffic laws without educating road users e.g. drivers, pedestrians will not work in making safer roads. Moreover, perspectives on road safety and intervention are not limited to the six 'E's described here. Going further, one could consider the impact on mental wellbeing of a well-designed road space, or the impact on emissions and air quality and the encouragement of active travel.

Systems based research is growing in popularity in high-income settings, with large majority of methods having been developed in high-income settings. Such a level of interest is yet to be seen in low- and middle-incomes countries, hence there is still a need to explore the impact of such research in these settings. Bangladesh being a low-income country, the road traffic scenario is quite different to that seen in high-income countries, for example through its nonlane based, heterogeneous traffic. The behaviour of its users can be considered more complex than that seen in the lane-based, homogenous traffic systems that prevail in high-income developed countries. Although methods like the Accimap have recently seen some use in these settings, the availability of such research is still very low. This is at least partly due to very limited data availability in those settings. As such, the development of proper collisions statistics databases is key. This provides an opportunity as well as a challenge; although such data collection will not be easy (given resource constraints in these settings), the road safety community has the chance to apply modern systems-thinking in the development of collision information databases that go beyond the end user and physical environment, thereby paving the way forward for increasing acceptability of systemic approaches to road traffic collision analysis.

\section{CONCLUSIONS}

Researchers around the world have emphasised the need to apply sociotechnical systems methods to the investigation of road traffic collisions in order to overcome the plateauing impact of traditional collision investigation methods. This paper focussed on adapting a systems-based sociotechnical approach, i.e., the Accimap methodology, to investigate two related road traffic incidents that occurred on a highway in Dhaka, Bangladesh. A single Accimap diagram was employed to graphically represent two interlinked collisions with an aim 
of highlighting the contribution of factors across different levels of the system to the occurrence of the incidents rather than blaming certain individuals, a blame culture that is clearly seen in traditional investigation methods in Bangladesh (and around the world). Further, intervention measures were proposed and described in terms of six road safety 'E's (education, enforcement, engineering, economics, enablement, emergency response), with each recommendation corresponding to an incident event as represented in the Accimap. From a practitioner and decision-maker's perspective, the advantage of graphically representing two inter-linked incidents via a single diagram lies in being capable of identifying the higher system factors responsible for causing the secondary collision. It was evident from the analysis that a lack of enforcement and emergency response services in the first collision contributed significantly to the second fatal incident. Bangladesh being a low-income country, inadequate enforcement and an underdeveloped emergency recovery system is prominent, and recommendations proposed from a systems perspective has the potential to reduce the likelihood of occurrence and resulting severity of similar incidents in the future. Although the shortfalls in enforcement and emergency response were most prominent, recommendations based on other ' $E$ 's should be taken in account; improvements at a systems level can be expected only if all aspects of the system are addressed. There is currently a lack of research in low-income settings (like Bangladesh), where complex road traffic systems are prevalent. As such, adopting systemic approaches to road traffic collisions, especially those involving vulnerable road users such as pedestrians, have great potential to guide road safety researchers, practitioners, and policymakers to build a better road transport system.

\section{Acknowledgments}

This research was funded by the National Institute for Health Research (NIHR; 16/137/122) using UK aid from the UK Government to support global health research. The views expressed in this publication are those of the author(s) and not necessarily those of the NIHR or the UK Department of Health and Social Care.

\section{References}

Accident Research Institute-ARI, 2015; Reporting and recording of road traffic accidents in Bangladesh.

Ahmed, I., Ahmed, B., 2013. Urban Road Accidents in Dhaka, Bangladesh. 16th Road Safety on Four Continents Conference, Beijing, China. 
BBC News, 2018. Bangladesh protests: How a traffic accident stopped a city of 18 million. Available from https://www.bbc.com/news/world-asia-45080129. Accessed on the $31^{\text {st }}$ of January, 2020.

Branford, K., 2011. Seeing the big picture of mishaps: applying the Accimap approach to analyse system accidents. Aviation Psychol. Appl. Human Factors 1 (1), 31-37.

Cassano-Piche, A. L., Vicente, K. J., \& Jamieson, G. A. (2009). A test of Rasmussen's risk management framework in the food safety domain: BSE in the UK. Theoretical Issues in Ergonomics Science, 10(4), 283-304.

Donovan, S.-L. Salmon, P.M., Lenné, M.G., Horberry, T., (2017). Safety leadership and systems thinking: application and evaluation of a risk management framework in the mining industry. Ergonomics, 60 (10), 1336-1350.

Goode, N., Salmon, P.M., Taylor, N.Z., Lenné, M.G., Finch, C.F., 2017. Developing a contributing factor classification scheme for Rasmussen's AcciMap: Reliability and validity evaluation. Applied Ergonomics, 64, 14-26.

Hamim, O.F., Hoque, M.S., 2019. Application of Accimap Methodology to Investigate the Bus Accident at Salehpur Bridge, Proceedings of the 21st International Summer Symposium (pp. 101-102). International Activities Center, Japan Society of Civil Engineers.

Hamim, O.F., Hoque, M.S., McIlroy, R.C., Plant, K.L., Stanton, N.A., 2020. A sociotechnical approach to accident analysis in a low-income setting: Using Accimaps to guide road safety recommendations in Bangladesh. Safety Science, 124.

Hamim, O.F., Hoque, M.S., McIlroy, R.C., Plant, K.L., Stanton, N.A., 2019. Applying the AcciMap methodology to investigate the tragic Mirsharai road accident in Bangladesh, Proceedings of the MATEC Web of Conferences, 277, 02019.

Heydari, S.; Hickford, A.; McIlroy, R.; Turner, J.; Bachani, A.M., 2019. Road Safety in LowIncome Countries: State of Knowledge and Future Directions. Sustainability, 11, 6249.

Hollnagel, E., 2004. Barriers and Accident Prevention, Ashgate, Aldershot, UK.

Hollnagel, E., Speziali, J., 2008. Study on Developments in Accident Investigation Methods: A Survey of the "State-of-the-Art". SKI Report 2008:50.

Jenkins, D.P., Salmon, P.M., Stanton, N.A., Walker, G.H., 2010. A systemic approach to accident analysis: a Case Study of the Stockwell Shooting. Ergonomics 53, 1e17.

Lansdown, T.C., Stephens, A.N., Walker, G.H., 2015. Multiple driver distractions: a systemic transport problem. Accident Analysis and Prevention, 74, 360-367. 
Larsson, P., Dekker, S.W., Tingvall, C., 2010. The need for a systems theory approach to road safety? Safety Science, 48 (9), 1167-1174.

Larue, G.S., Blackman, R.S., Freeman, J., 2020. Frustration at congested railway level crossings: How long before extended closures result in risky behaviours?. Applied Ergonomics, 82.

Le Coze, J.E., 2015. Reflecting on Jens Rasmussen's legacy. A strong program for a hard problem. Safety Science, 71, 123-141. Part B.

Lee, S., Moh, B.Y., Tabibzadeh, M., Meshkati, N., 2017. Applying the AcciMap methodology to investigate the tragic Sewol Ferry accident in South Korea. Applied Ergonomics, 59, $517-$ 525, Part B.

Leveson, N., 2004. A new accident model for engineering safer systems. Safety Sci. 42, 237 270.

McIlroy, R.C., Plant, K.A., Hoque, M.S., Wu, J., Kokwaro, G.O., Nam, V.H., \& Stanton, N.A, 2019. Who is responsible for global road safety? A cross-cultural comparison of Actor Maps. Accident Analysis and Prevention, 122, 8-18.

Metaxatos, P., Sriraj, P.S., 2012. Advancing pedestrian safety at rail grade crossings. Transp. Res. Rec..

Murphy, L.A., Huang, Y., Robertson, M.M., Jeffries, S., Dainoff, M.J., 2018. A sociotechnical systems approach to enhance safety climate in the trucking industry: Results of an in-depth investigation. Applied Ergonomics, 66, 70-81.

Nayak, R., \& Waterson, P., 2016. 'When Food Kills': A socio-technical systems analysis of the UK Pennington 1996 and 2005 E. coli O157 Outbreak reports. Safety Science, 86, 3647.

Newnam, S., Goode, N., 2015. Don't blame the driver: a systems analysis of the causes of road freight crashes. Accident Analysis and Prevention, 76, 141-151.

Nyman, M. R., \& Johansson, M. (2015). Merits of using a socio-technical system perspective and different industrial accident investigation methods on accidents following natural hazards - a case study on pluvial flooding of a Swedish railway tunnel 2013. International Journal of Disaster Risk Reduction, 13, 189-199.

Parnell, K.J., Stanton, N.A., Plant, K.L., 2017. What's the law got to do with it? Legislation regarding in-vehicle technology use and its impact on driver distraction. Accident Analysis and Prevention, 100, 1-14. 
Plant, K.L., McIlroy, R.C., Stanton, N.A., 2018. Taking a '7 E's' approach to road safety in the UK and beyond. Contemporary Ergonomics and Human Factors 2018. Eds. Rebecca Charles and John Wilkinson. CIEHF.

Portney, L.G., Watkins, M.P., 2000. Foundations of Clinical Research: Applications to practice. Prentice Hall, New Jersey.

Rasmussen, J., 1997. Risk management in a dynamic society: a modeling problem. Safety Science, 27, 183-213.

Salmon, P., Williamson, A., and Lenné, M., et al. 2010. Systems-based accident analysis in the led outdoor activity domain: Application and evaluation of a risk management framework. Ergonomics 53(8): 927-939.

Salmon, P.M., Cornelissen, M., Trotter, M.J., 2012. Systems-based accident analysis methods: a comparison of Accimap, HFACS, and STAMP. Safety Science, 50, 1158-1170.

Scott-Parker, B., Goode, N., Salmon, P., 2015. The driver, the road, the rules... and the rest? A system-based approach to young driver road safety. Accident Analysis and Prevention, $75,297-305$.

Stanton, N.A., Salmon, P.M., Walker, G.H., Stanton, M., 2019. Models and methods for collision analysis: A comparison study based on the Uber collision with a pedestrian. Safety Science, 120, 117-128.

Stefanova, T., Burkhardt, J.M., Filtness, A., Wullems, C., Rakotonirainy, A., Delhomme, P., 2015. Systems-based approach to investigate unsafe pedestrian behaviour at level crossings. Accident Analysis and Prevention, 81, 167-186.

Svedung, I., Rasmussen, J., 2000. Proactive Risk Management in a Dynamic Society, first ed. Raddningsverket, Risk and Environmental Department. Swedish Rescue Services Agency, Karlstad, Sweden.

Tabibzadeh, M., Meshkati, N., 2015. Applying the AcciMap methodology to investigate a major accident in offshore drilling: A systematic risk management framework for oil and gas industry. In SPE Western Regional Meeting. Society of Petroleum Engineers.

Talbot, R., Fagerlind, H., Morris, A., 2013. Exploring inattention and distraction in the SafetyNet Accident Causation Database. Accid. Anal. Prev. 60, 445-455.

The Daily Star, 2019. Road crashes on rise despite govt measures. Available from https://www.thedailystar.net/frontpage/news/road-crashes-rise-despite-govt-measures-

1717696. Accessed on the 11th of January, 2019. 
Trotter, M.J., Salmon, P.M., Lenne, M.G., 2013. Improvisation: theory, measures and known influencing factors. Theoretical Issues in Ergonomics Science, 14 (5), 475-498.

Trotter, M.J., Salmon, P.M., Lenne, M.G., 2014. Impromaps: applying Rasmussen's risk management framework to improvisation incidents. Safety Science, 64, 60-70.

Underwood, P., Waterson, P.E., 2014. Systems thinking, the Swiss Cheese Model and accident analysis: a comparative systemic analysis of the Grayrigg train derailment using the ATSB, Accimap and STAMP models. Accident Analysis and Prevention, 68, 75-94.

Vicente, K.J., Christoffersen, K., 2006. The walkerton E. coli outbreak: a test of Rasmussen's framework for risk management in a dynamic society. Theor. Issues Ergonomics Sci. 7, $93 \mathrm{e} 112$.

Warmerdam, A., Newnam, S., Sheppard, D., Griffin, M., Stevenson, M., 2017. Workplace road safety risk management: an investigation into Australian practices. Accid. Anal. Prev. 98, $64-73$.

Waterson, P.E. and Jenkins, D.P., 2011. Lessons learnt from using Accimaps and the risk management framework to analyse large-scale systemic failures. IN: Anderson, M. (ed.). Contemporary Ergonomics and Human Factors 2011. Proceedings of the International Conference on Contemporary Ergonomics and Human Factors 2011. London: Taylor and Francis.

Waterson, P.E., 2020. Causation, levels of analysis and explanation in systems ergonomics A Closer Look at the UK NHS Morecambe Bay investigation. Applied Ergonomics, 84, 2020.

Waterson, P.E., Jenkins, D.P., Salmon, P.M., Underwood, P., 2017. 'Remixing Rasmussen': the evolution of Accimaps within systemic analysis. Applied Ergonomics, 59 (Part B), 483-503.

Waterson, P.E., Robertson, M.M., Cooke, N.J., Militello, L., Roth, E., Stanton, N.A., 2015. Defining the methodological challenges and opportunities for an effective science of sociotechnical systems and safety. Ergonomics 58, 650-658.

WHO, 2018. Global Status Report on Road Safety 2018. World Health Organisation, Geneva. Young, K.L., Salmon, P.M., 2015. Sharing the responsibility for driver distraction across road transport systems: A systems approach to the management of distracted driving. Accident Analysis and Prevention, 74, 350-359. 